\title{
Progress towards malaria elimination in Sabang Municipality, Aceh, Indonesia
}

Herdiana Herdiana ${ }^{1 *}$, Anis Fuad ${ }^{2}$, Puji BS Asih ${ }^{3}$, Siti Zubaedah ${ }^{4}$, Risalia Reni Arisanti', Din Syafruddin³, Hari Kusnanto ${ }^{2}$, Maria Endang Sumiwi ${ }^{1,3}$, Titik Yuniarti ${ }^{5}$, Ali Imran ${ }^{5}$, Rahmadyani Rahmadyani ${ }^{6}$, Muhammad Yani ${ }^{6}$, Rita Kusriastuti ${ }^{4}$, Siti Nadia Tarmizi ${ }^{4}$, Ferdinand J Laihad ${ }^{1}$ and William A Hawley ${ }^{1 *}$

\begin{abstract}
Background: Indonesia has set 2030 as its deadline for elimination of malaria transmission in the archipelago, with regional deadlines established according to present levels of malaria endemicity and strength of health infrastructure. The Municipality of Sabang which historically had one of the highest levels of malaria in Aceh province aims to achieve elimination by the end of 2013.

Method: From 2008 to 2010, baseline surveys of malaria interventions, mapping of all confirmed malaria cases, categorization of residual foci of malaria transmission and vector surveys were conducted in Sabang, Aceh, a pilot district for malaria elimination in Indonesia. To inform future elimination efforts, mass screening from the focal areas to measure prevalence of malaria with both microscopy and PCR was conducted. G6PD deficiency prevalence was also measured.
\end{abstract}

Result: Despite its small size, a diverse mixture of potential malaria vectors were documented in Sabang, including Anopheles sundaicus, Anopheles minimus, Anopheles aconitus and Anopheles dirus. Over a two-year span, the number of sub-villages with ongoing malaria transmission reduced from 61 to 43 . Coverage of malaria diagnosis and treatment, IRS, and LLINs was over 80\%. Screening of 16,229 residents detected 19 positive people, for a point prevalence of $0.12 \%$. Of the 19 positive cases, three symptomatic infections and five asymptomatic infections were detected with microscopy and 11 asymptomatic infections were detected with PCR. Of the 19 cases, seven were infected with Plasmodium falciparum, 11 were infected with Plasmodium vivax, and one subject was infected with both species. Analysis of the 937 blood samples for G6PD deficiency revealed two subjects (0.2\%) with deficient G6PD.

Discussion: The interventions carried out by the government of Sabang have dramatically reduced the burden of malaria over the past seven years. The first phase, carried out between 2005 and 2007, included improved malaria diagnosis, introduction of ACT for treatment, and scale-up of coverage of IRS and LLINs. The second phase, from 2008 to 2010, initiated to eliminate the persistent residual transmission of malaria, consisted of development of a malaria database to ensure rapid case reporting and investigation, stratification of malaria foci to guide interventions, and active case detection to hunt symptomatic and asymptomatic malaria carriers.

Keyword: Malaria control, Malaria elimination, Sabang municipality, Aceh, Indonesia

\footnotetext{
*Correspondence: hherdiana@unicef.org; whawley@unicef.org

${ }^{1}$ Child Survival and Development Cluster, UNICEF Indonesia Country Office,

Jalan Sudirman Kav. 31, Wisma Metropolitan II, Fl 10th, Jakarta 12920,

Indonesia

Full list of author information is available at the end of the article
}

\section{Biomed Central}

(C) 2013 Herdiana et al.; licensee BioMed Central Ltd. This is an Open Access article distributed under the terms of the Creative Commons Attribution License (http://creativecommons.org/licenses/by/2.0), which permits unrestricted use, distribution, and reproduction in any medium, provided the original work is properly cited. 


\section{Background}

Malaria is a major public health problem in most tropical countries, including Indonesia. Recent models estimate that over 105 million of Indonesia's 239 million population are at risk for malaria infection, with transmission varying widely across this most populous entirely tropical country [1]. Though formally reported deaths are less than 1,000 annually [2], recent work estimates that about 11,000 people die annually due to infections with Plasmodium falciparum [3]. The number of deaths caused by Plasmodium vivax infection is not known. The most recent WHO estimate of the number of deaths due to malaria is approximately 3,000 per year in Indonesia [2]. In 2009, the Indonesian MOH explicitly made malaria elimination a national goal, to be accomplished in a step-by-step, island-by-island fashion over the next several decades [4].

Sabang municipality in Aceh Province was once one of the most malarious areas in Indonesia [5]. Now, after successful control, with only sporadic focal transmission occurring, Sabang's government [6], with support from provincial and central authorities, is committed to eliminate malaria transmission by the end of the year 2013 [7].

This effort is in line with the recent rise of malaria elimination in the global public health agenda, signaled by the commitment of the 60th World Health Assembly in 2007 that all countries should commit to eliminate malaria by 2050 [8]. Indonesia aims to eliminate malaria by 2030 [4], while the target for low-endemic Aceh Province is 2015 [4,7]. In 2009, the Provincial Parliament of Aceh endorsed this plan, and budgeted significant resources towards its achievement. In addition, the Governor of Aceh has provided legal support to the plan via a new regulation promulgated in 2010 [7].

If the political and legal framework for malaria elimination in Indonesia and Aceh is in place, clear technical challenges remain. Indonesia straddles Wallace's line, and has perhaps two dozen known malaria vectors with a large variety of behaviours. Further, Indonesia has a high prevalence of both $P$. falciparum and $P$. vivax, which tremendously complicates the elimination effort $[9,10]$. Though decentralization of the government in 2000 (including decentralization of the health system) has resulted in some deterioration of services, some well-governed districts have risen to the challenge and have improved health service delivery [11].

In the context of Indonesia, Sabang District is an appropriate place to pilot malaria elimination by virtue of its geographic position at the western end of the archipelago, its diverse mosquito fauna, the presence of both major malaria parasites, and its strong local government. The rate of importation of malaria into Sabang is likely low, giving hope that the municipality will be able to maintain elimination in the long run. Sabang has, in general outline, followed the recommendations of the WHO for malaria elimination [8], while recognizing the necessity to adapt these guidelines according to circumstances on the ground in Sabang.

The effort has been led by the government of Sabang, with support from the Provincial Health Office of Aceh, the National Malaria Control Program of Indonesian Ministry of Health, University of Gadjah Mada, Eijkman Institute, the World Health Organization (WHO) and the United Nation Children Fund's (UNICEF).

This account begins with a description of what WHO terms the 'control' phase of malaria control [8], in which post-tsunami funding allowed rapid scale-up of IRS and LLINs, improved malaria diagnosis, and treatment with $\mathrm{ACT}$. The rapidly achieved high coverage ot these interventions resulted in a quick decline in malaria cases, but these persist at a low level [6]. The reorientation of activities aimed at moving the programme towards malaria elimination is then described. These efforts included intensive mapping of both vectors and malaria cases, establishment of a comprehensive database, and most recently, aggressive active case finding coupled with surveys to estimate G6PD prevalence and malaria parasite genotypes.

\section{Methods}

\section{Site}

The municipality of Sabang is located at the northwesternmost part of Indonesia, and is part of Aceh Province (Figure 1). The district has an area of $153 \mathrm{~km} 2$ covering five islands: Weh, Klah, Rubiah, Seulako, and Rondo [12]. Only the largest island, Weh, is permanently inhabited, though Rondo has a lighthouse attendant and Rubiah has inexpensive tourist shelters that are sometimes occupied. Thus, all but one of the municipality's official residents totaling 30,653 people live on Weh Island, which is divided administratively into two subdistricts and 18 villages [13].

Malaria occurs year-round in Sabang (Figure 2). An increase in cases is observed during the rainy season, but rain and malaria occur every month.

\section{History of malaria control in Sabang}

Malaria in Sabang was recognized by the government of Indonesia after an outbreak was reported in 1967 [5]. In 1970, Sabang was included in phase II of the Government of Indonesia's Malaria Eradication Programme (KOPEM), which was based on spraying with DDT (2 gr/m2 active ingredient) twice a year [14].

DDT spraying was effective, resulting in a drop in the prevalence of parasitaemia in school children from $37.0 \%$ in 1971 to $1.6 \%$ in 1975 . It remained below $7.5 \%$ until 1978. During the early 1980s, the prevalence of 


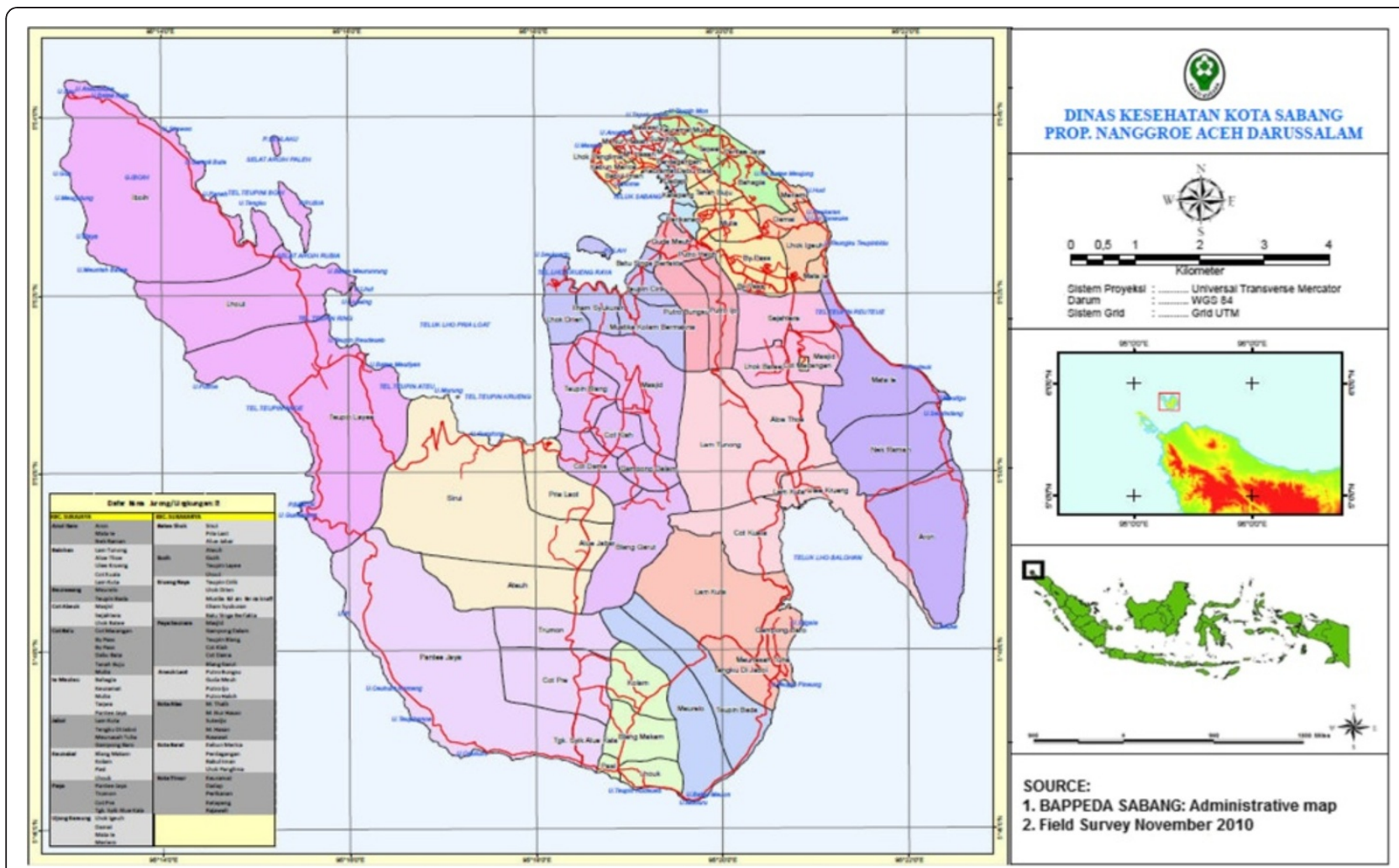

Figure 1 Map of Sabang Municipality and Weh Island showing position of Sabang in Indonesia and sub villages within the municipality.

parasitaemia in the overall population ranged from $7.5 \%$ to $10.4 \%$ [14]. After the malaria eradication campaign was abandoned, malaria remained as a major public health problem in Sabang. The situation worsened with appearance of choloroquine-resistant and sulphadoxinepyrimethamine-resistant in $P$. falsiparum Sabang in the late 1980s [15].
From 1990 to 2004, the malaria control programme in Sabang still emphasized IRS, though DDT was no longer used after 1994 [16]. From 1995 to 2000, Bendiocarb ${ }^{\circledR}$ was widely used in Sabang, while Vectron ${ }^{\circledR}$ (etofenprox) was used from 2001 to 2005. Despite the documented resistance of $P$. falciparum to chloroquine and SP, these drugs were still used for malaria treatment [17].

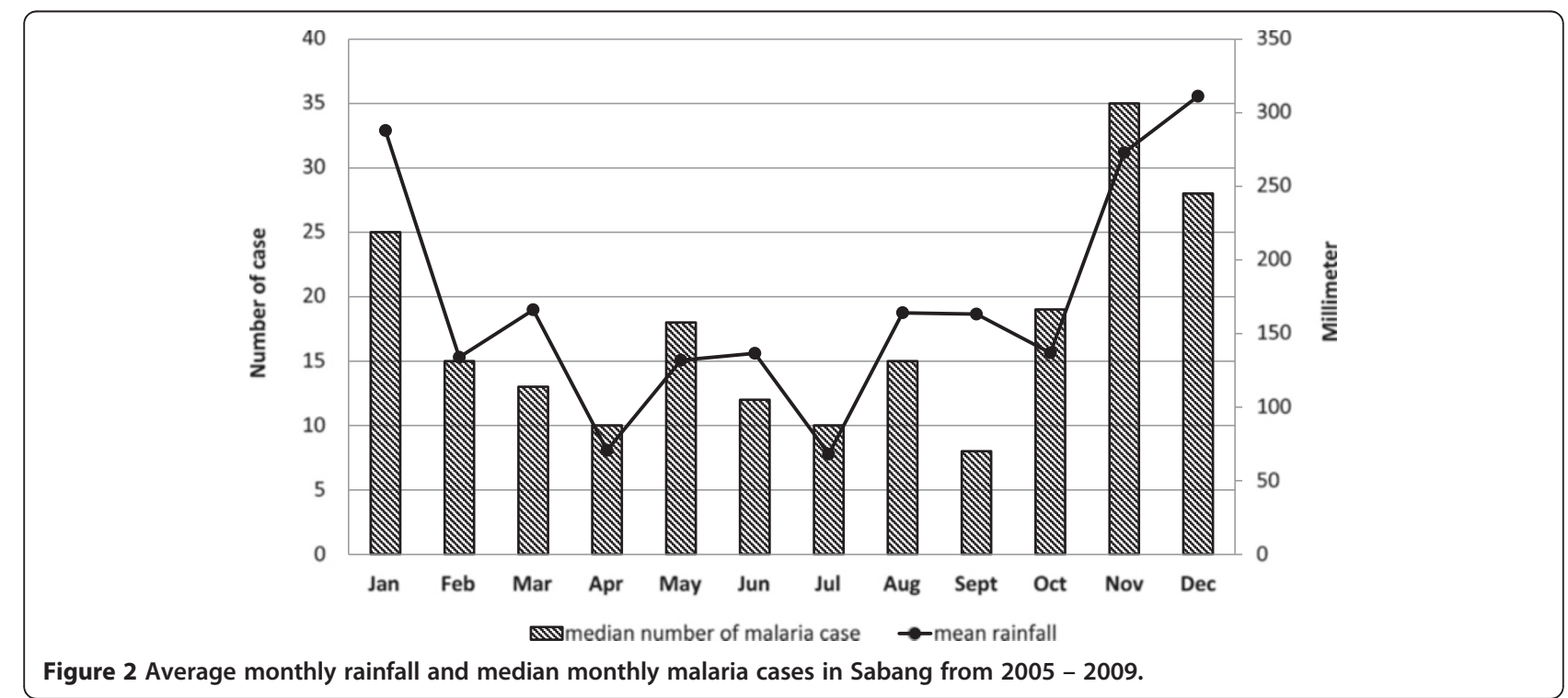


On 26 December 2004, the Indian Ocean tsunami devastated much of the west coast of Aceh, including parts of Sabang. Though the health infrastructure of the province was largely destroyed, with loss of both material and personnel, aid from the central government of Indonesia, various UN agencies and NGOs supported rapid recovery of the malaria programme and improvements in health infrastructure. Improvements in malaria control included an extensive IRS programme in the year immediately following the tsunami, large scale LLIN distribution, and a change in malaria treatment policy to ACT as first-line treatment for uncomplicated malaria. These efforts resulted in a rapid decrease in malaria, with reported incidence declining from 87.8 infections per 1,000 population in 2004 to four cases per thousand in 2007. The proportion of infections due to P. falciparum declined from $77 \%$ to $64 \%$ from 2002 to 2007 . No fatalities due to malaria have occurred post-tsunami [17]. The confirmed cases and interventions are depicted in Figure 3.

The studies of of Swellengrebel and Rodenwaltd in 1932 indicated four Anopheles species on Sabang, Anopheles minimus, Anopheles sundaicus, Anopheles subpictus and Anopheles vagus, while Hudson et al. identified five Anopheles species on Sabang during a dry season survey in 1985: Anopheles aconitus, Anopheles leucophyrus, Anopheles maculatus, Anopheles minimus and Anopheles sundaicus. Hudson et al. came to no definite conclusion as to the primary vectors due to small numbers of adults captured [14]. Since Hudson's work, no published vector evaluation report exists in local government archives.

The elimination programme was launched by the Indonesian Ministry of Health in 2008, and was followed by local government in 2009 [17]. With firm commitment and support from national, provincial, and district authorities, the District Health Office of Sabang was tasked with designing an effective technical approach that would lead the district to malaria elimination. After consultation with national malaria control programme, WHO experts, and UNICEF, four initial activities were planned and executed; e.g. mapping of malaria vectors; mapping of malaria cases; determination of residual foci of malaria transmission; and mass population screening to detect asymptomatic cases. These activities, which were carried out from 2008 to 2010, are described below.

\section{Vector assessment}

Mosquito surveys were done in all villages in Sabang from August - November 2008. Surveys were carried out in each of 18 villages.

All night human landing collections were carried out in three houses in each village, with one person indoors and one person outdoors in each of the three houses. Collections were carried out from 7:00 pm until 7:00 am over a period of 18 nights. As sunset in Sabang is approximately 6:45 pm and sunrise is at 6:30 am, collections were carried out from just after dusk until just after dawn. Collectors used aspirators to catch mosquitoes

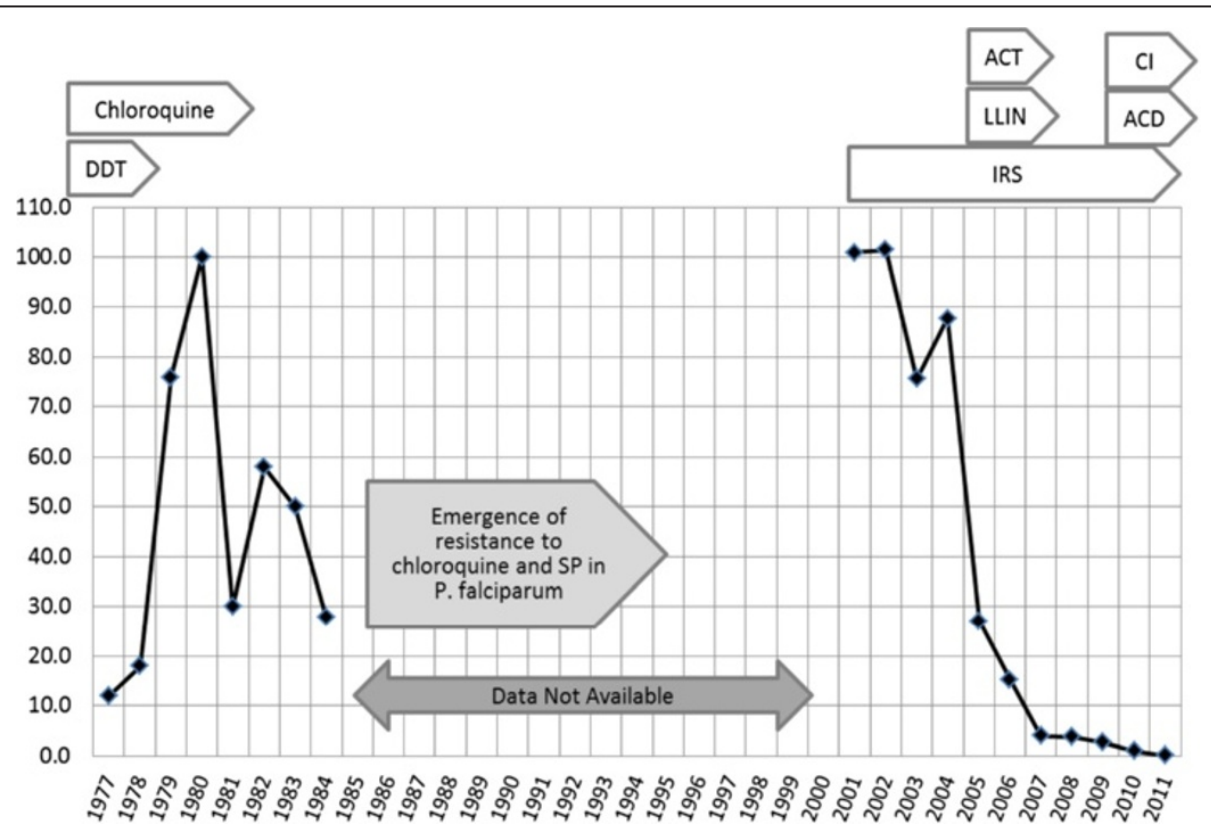

Figure 3 Confirmed malaria cases per thousand population in Sabang based upon available passive surveillance data, showing major interventions and drugs used for treatment from 1977 to 2011. DDT: dichlorodiphenyltrichloroethane, ACT: Artemisinin-based Combination Therapy, LLIN: Long Lasting Insectiside Treated Bednets, IRS: Indoor Residual Spraying, Cl: Case Investigation, ACD: Active Case Detection. 
coming to bite. Mosquitoes were stored in labeled cups for further processing.

During night collections, collectors worked for 10 minutes each hour collecting indoor resting mosquitoes using an aspirator. Morning resting collections were carried out indoors and outdoors near the night collection stations.

Larval collections aimed to sample as great a variety of habitats as possible with particular attention to areas known to have ongoing malaria transmission. Anopheles larvae were counted and taken to the laboratory for identification. Larval habitats were characterized for the following: type of sites; distance to the nearest house, water quality (clear, cloudy or muddy), amount of sunlight (full sun, full shade or mixed), presence and type of vegetation, and the presence of other mosquito genera and invertebrate predators $[18,19]$. GPS coordinates were recorded for each site sampled.

All adult mosquitos were morphologically identified in the laboratory using keys developed by Reid [20] and O'Connor \& Soetanto [21]. Hourly man biting rates indoors and outdoors were calculated; host preferences; and indoor and outdoor resting habits were described [22].

\section{Development of malaria map and database}

To develop the basis for surveillance and rapidly respond to infections, available malaria baseline data at household level were incorporated into a GIS system to support implementation of malaria elimination. Design of the database included wide consultation, including focus group discussions with the District Planning Board, Civil Registration Office, District Health Office, Health Division of the Armed Forces, Center of Data and Information under the Mayor of Sabang, and sub district leaders. Both routine and survey data were incorporated into the database. A cross sectional census and survey in six villages selected on the basis of their continued malaria endemicity over the most recent three-year period was conducted. The survey was carried out from March to June 2009 in the villages of Paya Seunara, Balohan, Jaboi, Batee Shok, Krueng Raya and Keneukai. The questionnaire included demographic data, malaria risk factors and measurement of coverage of IRS and LLINs. All houses in each village were surveyed and mapped with GPS.

In addition to the household survey, routine surveillance data from the municipal health authority from health centres for 2007 and 2008 were reviewed, collated and incorporated into the database. Malaria cases were listed and each household visited. A standard questionnaire was administered to the index case or an older relative in instances where the case was a minor.
Information from the interview and GPS coordinates were entered into the database [23]. Information on population characteristics from civil authorities of Sabang was also incorporated in the database.

A desk review of secondary data from 2009 and 2010 to determine foci of malaria transmission was conducted. Foci was stratified and mapped twice, in July 2009 and December 2010 [17].

Analysis was carried out and maps and graphics produced using spatial analysis software (SatScan), Epi Info version 3.3.2 and Excel.

\section{Mass blood screening}

In May to October 2010, mass blood screening in 14 villages with known malaria transmission was carried out. Urban areas with no recorded transmission were excluded from the survey. In all, 14,462 individuals were surveyed from the target population of 19,443 (74\% of target). For these samples, the village of origin of each subject was known. An additional 1,767 subjects in schools and government offices for which unrecorded household of residence were also surveyed. For each individual, thick and thin blood smears and blood spots with filter paper No.1 (Whatman International, Maidstone, Kent, UK) were collected [24]. All slides were reviewed by expert microscopists. Location of confirmed positive cases was geocoded with GPS. All positive cases were confirmed with PCR. 1,181 negative samples from asymptomatic subjects were tested with PCR, with the samples selected weighted towards villages with known positive cases [25].

Blood samples from randomly-selected household in this survey were checked for the presence of glucose-6-phosphate dehydrogenase (G6PD) deficiency. For this test, $5 \mu$ l of whole blood was taken by finger puncture with a micropipette and a disposable tip, and mixed with the reaction solution for G6PD in a $1.5-\mathrm{ml}$ microcentrifuge tube (Eppendrof). In the field, qualitative assays used water-soluble tetrazolium salt, WST-8, that also produces water-soluble formazan which are included in the Dojindo test kit (Dojindo Laboratories, Tokyo, Japan) [26].

Additionally, all dried blood spots in filter paper were sent to the Eijkman Institute, Jakarta for molecular analysis. DNA was extracted by chelex-100 ion exchanger (Biorad Laboratories, Hercules, CA) $[27,28]$. Three exons were analysed using polymerase chain reaction amplification and restriction fragment length polymorphisms (PCR/ RFLP) to determine the most common known mutations for G6PD deficiency in Indonesia such as (Mediterranian (563C/T), Coimbra (592 C/T), Vianchang Canton (1376 G/T), Vanua Lava (383 T/C), Mahidol (487 G/T), Chatam (1003 G/A), Kaiping (1388 G/A), Vianchang (871 G/A, $1311 \mathrm{C} / \mathrm{T})$ [29-31]. 


\section{Results}

Vector assessment

Twenty-three adult Anopheles were collected during six nights of all night collections, including $11 \mathrm{An}$. aconitus, four Anopheles dirus, three Anopheles flavirostris, two An. sundaicus, one each of An. subpictus and An. minimus and one unidentified. Four anophelines were captured indoors (An. subpictus, An. flavirostris and An. aconitus) and 19 were collected outdoors (An. dirus, An. sundaicus, An. flavirostris, An. minimus, An. aconitus). All mosquitoes were collected after $9 \mathrm{pm}$. No mosquitoes were collected in the resting collections. Adult Anopheles mosquitoes were captured in the villages of Krueng Raya, Anoi Itam, Jaboi, Iboih, Paya Seunara and Batee Shok. A table of breeding sites with Anophelines and villages where adult and larval Anopheline mosquitoes were captured is shown in Tables 1 and 2 .

Survey teams sampled 211 potential larval habits throughout Sabang; immature stages of Anopheles mosquitoes were present in 61 (29\%) sites. A total of 423 larvae and pupae were collected from 10 species: An. aconitus, An. dirus, An. sundaicus, An. subpictus, Anopheles montanus, Anopheles barbirostris, Anopheles kochi, Anopheles umbrosus, Anopheles hyrcanus sp, and An. vagus. This represents the first report of $A n$. dirus from Indonesia. Details on the sites sampled are shown in Tables 1 and 2, and examples of anopheles larval habitats are depicted in Figure 4.

Paya Seunara and Krueng Raya villages were those with the greatest number of larval specimens, with 59 and 56 immatures captured, respectively [22].

\section{Development of malaria map and database}

For the baseline malaria survey, 1,446 households from two subdistricts were interviewed and mapped using GPS. Data on demographics, malaria risk factors, and coverage of malaria prevention activities were collected using a standard questionnaire. Forty-two percent of $\mathrm{HHs}$ from Sukajaya Subdistrict (from the villages of Balohan, Jaboi, and Keunekei) and 58\% of HHs from Sukakarya Subdistrict (from the villages of Batee Shok, Paya Seunara and Krueng Raya) were included in the survey.

Nearly all (99.5\%) of respondents lived in houses with the balance living in dormitories or boarding schools. Over half of households (57\%) lived in hilly areas, while $20 \%$ lived in coastal areas. Forty seven percent lived near plantations, while others lived near brushwood (16\%); forest (14\%); lagoon (7\%); river (5\%); ponds (4\%); lake $(0.1 \%)$ or unclassified (7\%).

Most households stated that their preferred method for prevention of malaria was use of LLINs (73\%), while $12 \%$ preferred use of repellents or mosquito coils, and $11 \%$ preferred elimination of larval mosquito habitats.

Survey data are consistent with high coverage of both LLINs and IRS in Sabang, as summarized in Figure 5. For the six villages in the area of residual transmission in Sabang, two villages (Paya Seunara and Kreung Raya) have coverage of both IRS and LLINs over $75 \%$, while all other villages have coverage of at least one of the two major prevention activities of over $75 \%$. However, it was noted that $8 \%$ of houses have received neither intervention.

Malaria cases in 2007 and 2008 were mapped. In 2007, 144 cases of malaria were reported by the Municipal

Table 1 Results of larval surveys in Sabang

\begin{tabular}{|c|c|c|c|c|}
\hline \multirow[b]{2}{*}{ Type sites inspected } & \multirow[b]{2}{*}{$\begin{array}{l}\text { No. sites } \\
\text { inspected }\end{array}$} & \multicolumn{2}{|l|}{ Larva surveys } & \multirow[b]{2}{*}{ Type species } \\
\hline & & $\begin{array}{l}\text { No. sites with } \\
\text { Anopheles }\end{array}$ & $\%$ & \\
\hline Stream & 43 & 12 & $28 \%$ & $\begin{array}{l}\text { An. aconitus; An. barbirostris; An. montanus; An. subpictus; An. } \\
\text { umbrosus; An. vagus }\end{array}$ \\
\hline Ditch & 28 & 5 & $18 \%$ & An. vagus \\
\hline Pond & 41 & 12 & $29 \%$ & $\begin{array}{c}\text { An. barbirostris; An. montanus; An. subpictus; An. sundaicus; An. } \\
\text { vagus }\end{array}$ \\
\hline Ground pool & 32 & 17 & $53 \%$ & An. barbirostris; An. sundaicus; An. umbrosus; An. vagus \\
\hline Swamp & 2 & 1 & $50 \%$ & An. dirus; \\
\hline Water pool & 23 & 5 & $22 \%$ & An. aconitus: An. kochi; An. montanus; An. sundaicus; An. vagus \\
\hline Lake & 2 & 1 & $50 \%$ & An. barbirostris; An. vagus \\
\hline Hoof-print & 24 & 6 & $25 \%$ & An. montanus; An. vagus \\
\hline Flower Vase & 1 & 0 & $0 \%$ & - \\
\hline Drum & 9 & 0 & $0 \%$ & - \\
\hline Seepage & 2 & 1 & $50 \%$ & Anopheles Sp L2 \\
\hline $\begin{array}{l}\text { Water container made of } \\
\text { cement }\end{array}$ & 3 & 0 & $0 \%$ & - \\
\hline Lagoon & 1 & 1 & $100 \%$ & An. sundaicus \\
\hline Total & 211 & 61 & & \\
\hline
\end{tabular}


Table 2 Villages with larval habitats with anophelines and results of landing and resting collection by village

\begin{tabular}{|c|c|c|c|c|c|c|c|}
\hline \multirow[t]{2}{*}{ Village } & \multirow{2}{*}{$\begin{array}{l}\text { Total } \\
\text { no. } \\
\text { dips }\end{array}$} & \multicolumn{2}{|c|}{ Larval survey } & \multirow[t]{2}{*}{ Type species } & \multicolumn{2}{|c|}{ Landing catch } & \multirow[t]{2}{*}{ Resting } \\
\hline & & $\begin{array}{l}\text { No. sites } \\
\text { inspected }\end{array}$ & $\begin{array}{l}\text { No. sites with } \\
\text { Anopheles }\end{array}$ & & $\begin{array}{l}\text { No. Anopheles } \\
\text { indoors }\end{array}$ & $\begin{array}{l}\text { No. Anopheles } \\
\text { outdoors }\end{array}$ & \\
\hline Kota Atas & 0 & 4 & 0 & - & 0 & 0 & 0 \\
\hline $\begin{array}{l}\text { Kota Bawah } \\
\text { Barat }\end{array}$ & 25 & 5 & 0 & - & 0 & 0 & 0 \\
\hline $\begin{array}{l}\text { Kota Bawah } \\
\text { Timur }\end{array}$ & 128 & 16 & 2 & An.sundaicus & 0 & 0 & 0 \\
\hline Aneuk Laot & 91 & 14 & 3 & An. dirus, An. barbirostris, An.sp & 0 & 0 & 0 \\
\hline \multirow{4}{*}{$\begin{array}{l}\text { Krueng } \\
\text { Raya }\end{array}$} & \multirow[t]{4}{*}{155} & \multirow[t]{4}{*}{18} & \multirow[t]{4}{*}{9} & \multirow{4}{*}{$\begin{array}{l}\text { An. subpictus; An. montanus; An. aconitus; An. vagus; } \\
\text { An.sundaicus }\end{array}$} & 2 & 4 & \multirow[t]{4}{*}{0} \\
\hline & & & & & $\begin{array}{l}\text { An. subpictus } \\
\text { (1) }\end{array}$ & An.dirus (1) & \\
\hline & & & & & An.aconitus (1) & $\begin{array}{l}\text { An.sundaicus } \\
\text { (2) }\end{array}$ & \\
\hline & & & & & & $\begin{array}{l}\text { An.flavirostris } \\
\text { (1) }\end{array}$ & \\
\hline \multirow{2}{*}{$\begin{array}{l}\text { Paya } \\
\text { Seunara }\end{array}$} & \multirow[t]{2}{*}{105} & \multirow[t]{2}{*}{11} & \multirow[t]{2}{*}{4} & \multirow[t]{2}{*}{ An. barbirostris; An. vagus; Hyrcanus group } & \multirow[t]{2}{*}{0} & 1 & \multirow[t]{2}{*}{0} \\
\hline & & & & & & $\begin{array}{l}\text { An.flavirostris } \\
\text { (1) }\end{array}$ & \\
\hline Keunekei & 75 & 8 & 7 & An. umbrosus, An. sundaicus, An. vagus & 0 & 0 & 0 \\
\hline $\begin{array}{l}\text { Paya } \\
\text { Keunekei }\end{array}$ & 85 & 7 & 3 & An. sundaicus; An. vagus; An. barbirostris & 0 & 0 & 0 \\
\hline \multirow[t]{2}{*}{ Iboih } & \multirow[t]{2}{*}{105} & \multirow[t]{2}{*}{13} & \multirow[t]{2}{*}{2} & \multirow[t]{2}{*}{ An. vagus; An.sp } & \multirow[t]{2}{*}{0} & 3 & \multirow[t]{2}{*}{0} \\
\hline & & & & & & An.dirus (3) & \\
\hline \multirow[t]{3}{*}{ Batee Shok } & \multirow[t]{3}{*}{117} & \multirow[t]{3}{*}{14} & \multirow[t]{3}{*}{3} & An. vagus & 0 & 2 & 0 \\
\hline & & & & & & An.minimus (1) & \\
\hline & & & & & & An.sp (1) & \\
\hline Jaboi & 111 & 13 & 6 & An. aconitus; An. umbrosus; An. kochi; An. barbirostris; & 1 & 7 & 0 \\
\hline & & & & An. vagus; An. montanu & An.aconitus (1) & An.aconitus (7) & \\
\hline Cot Bau & 67 & 11 & 2 & An. vagus; An. sp & 0 & 0 & 0 \\
\hline Cot Abeuk & 105 & 11 & 2 & An. barbirostris & 0 & 0 & 0 \\
\hline Anoi Item & 168 & 19 & 7 & An. vagus; An. subpictus & 1 & 2 & 0 \\
\hline & & & & & $\begin{array}{l}\text { An.flavirostris } \\
\text { (1) }\end{array}$ & An.aconitus (2) & \\
\hline $\begin{array}{l}\text { Ujung } \\
\text { Kareng }\end{array}$ & 71 & 13 & 2 & An. vagus, An.sp & 0 & 0 & 0 \\
\hline le Meulee & 49 & 7 & 1 & An. vagus & 0 & 0 & 0 \\
\hline Beurawang & 35 & 8 & 0 & - & 0 & 0 & 0 \\
\hline Balohan & 114 & 19 & 8 & An. vagus, An. subpictus, An.sp & 0 & 0 & 0 \\
\hline Total & 1606 & 211 & 61 & & 4 & 19 & 0 \\
\hline
\end{tabular}

Health Authority (MHA) of Sabang; of these 130 were traced back to the case's house. In 2008, 130 cases were officially reported by the MHA, but our survey team found 211 respondents who claimed that they had been diagnosed with malaria. This discrepancy is reasonable since the official data mostly depends on passivelycollected primary health centre reports. In all, 319 malaria cases were geocoded, as shown in Figure 6. More than half of villages in Sabang had malaria cases, with more than half of cases in Batee Shok, Balohan, Paya Seunara, Krueng Raya, and Jaboi.

Based upon geocoded cases and population distribution, $88 \%$ of households in Sabang live within 250 metres of a malaria case, while $96 \%$ of household live within 500 metres of a malaria case. In addition, the analysis showed that $41 \%$ of households live within 250 metres of known larval habitats of Anopheles mosquitoes. 


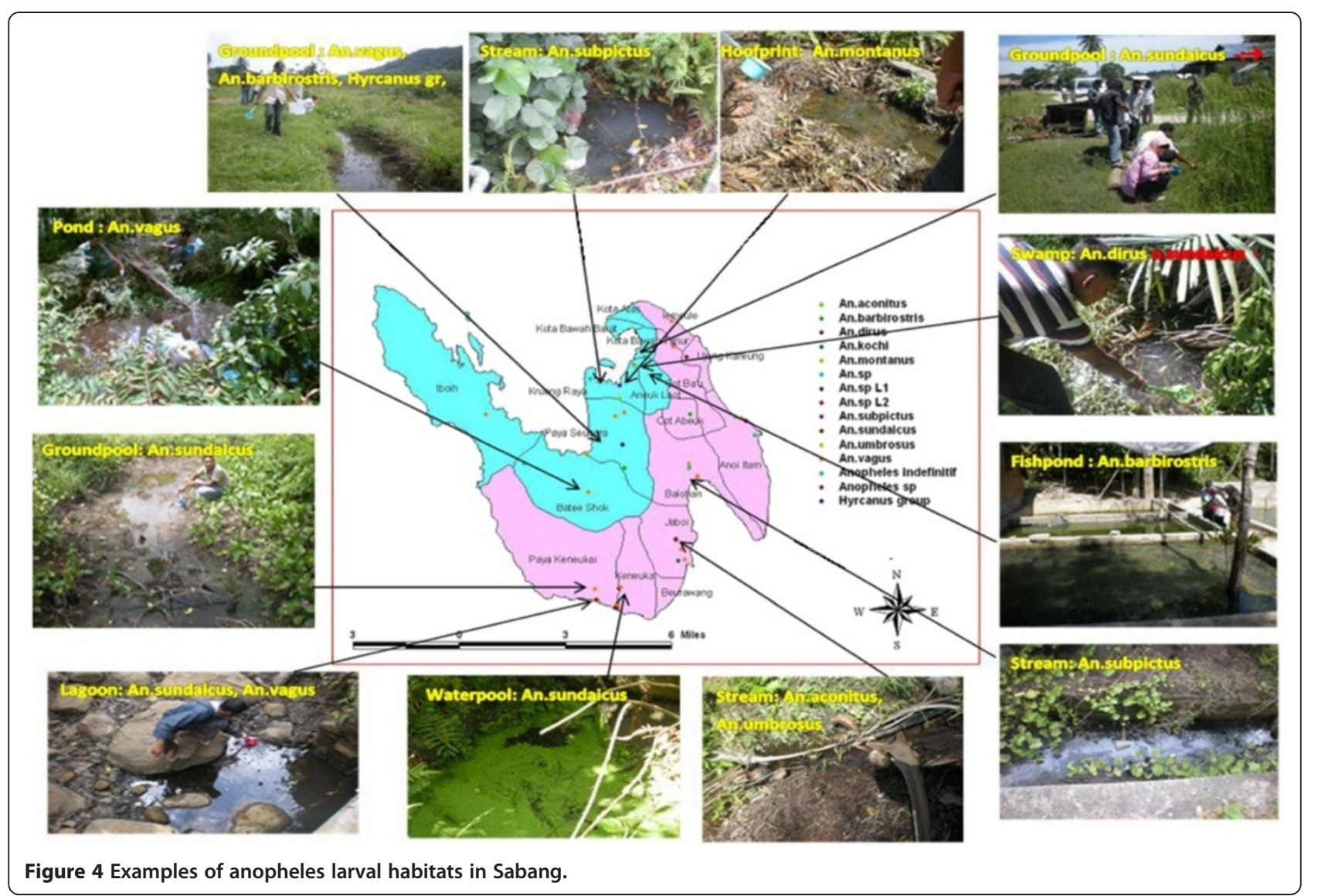

Before introduction of malaria elimination data management system, the MHA collected monthly data manually, most of which were gleaned from the microscopist's laboratory registers. The frequency of reporting (monthly) was clearly inadequate for malaria elimination; further, no standard reporting form existed. To improve speed and accuracy of reporting of malaria cases to the MHA, a database management system was designed to allow both manual and electronic entry data at every level of the health system. The system

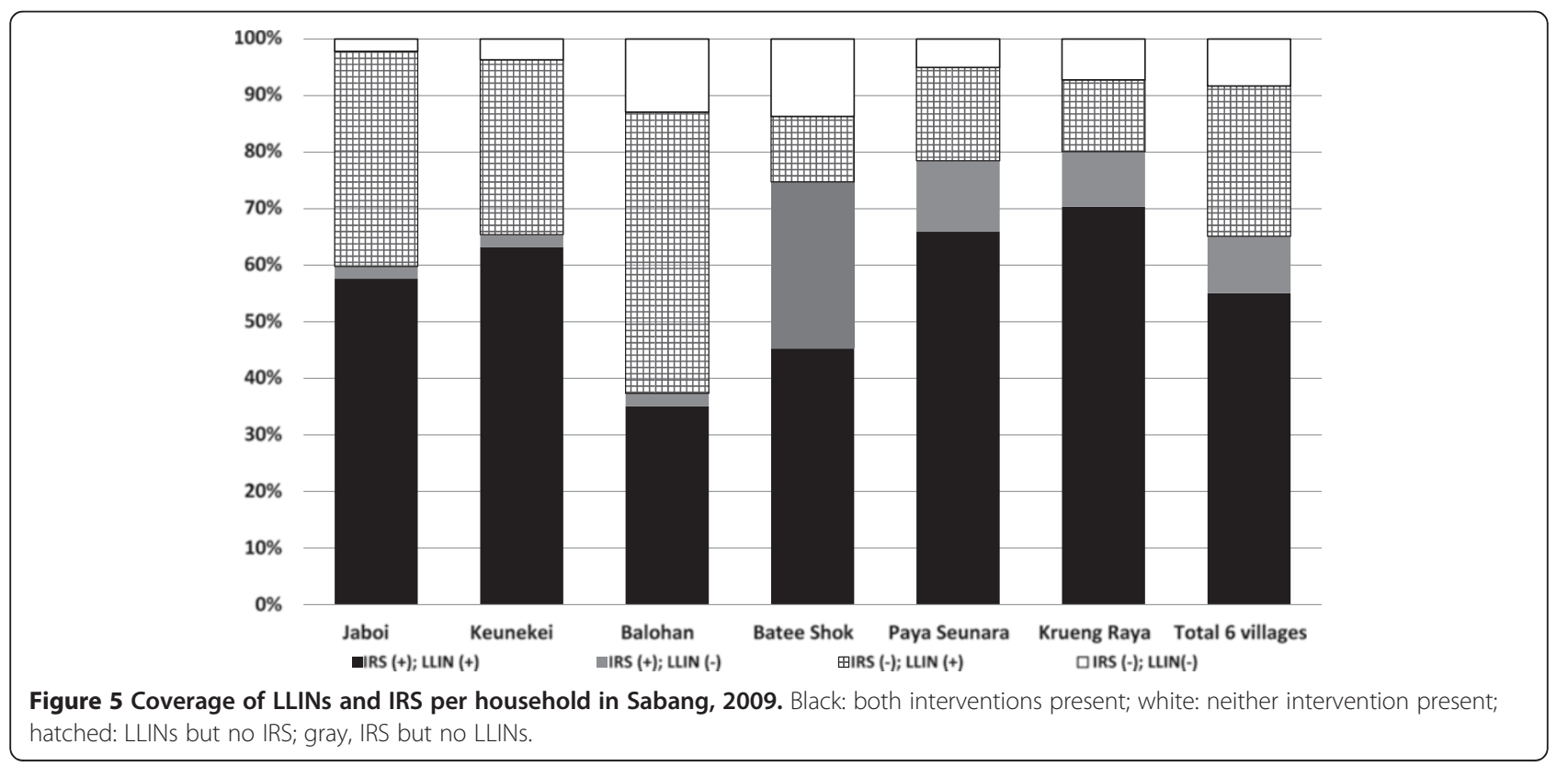




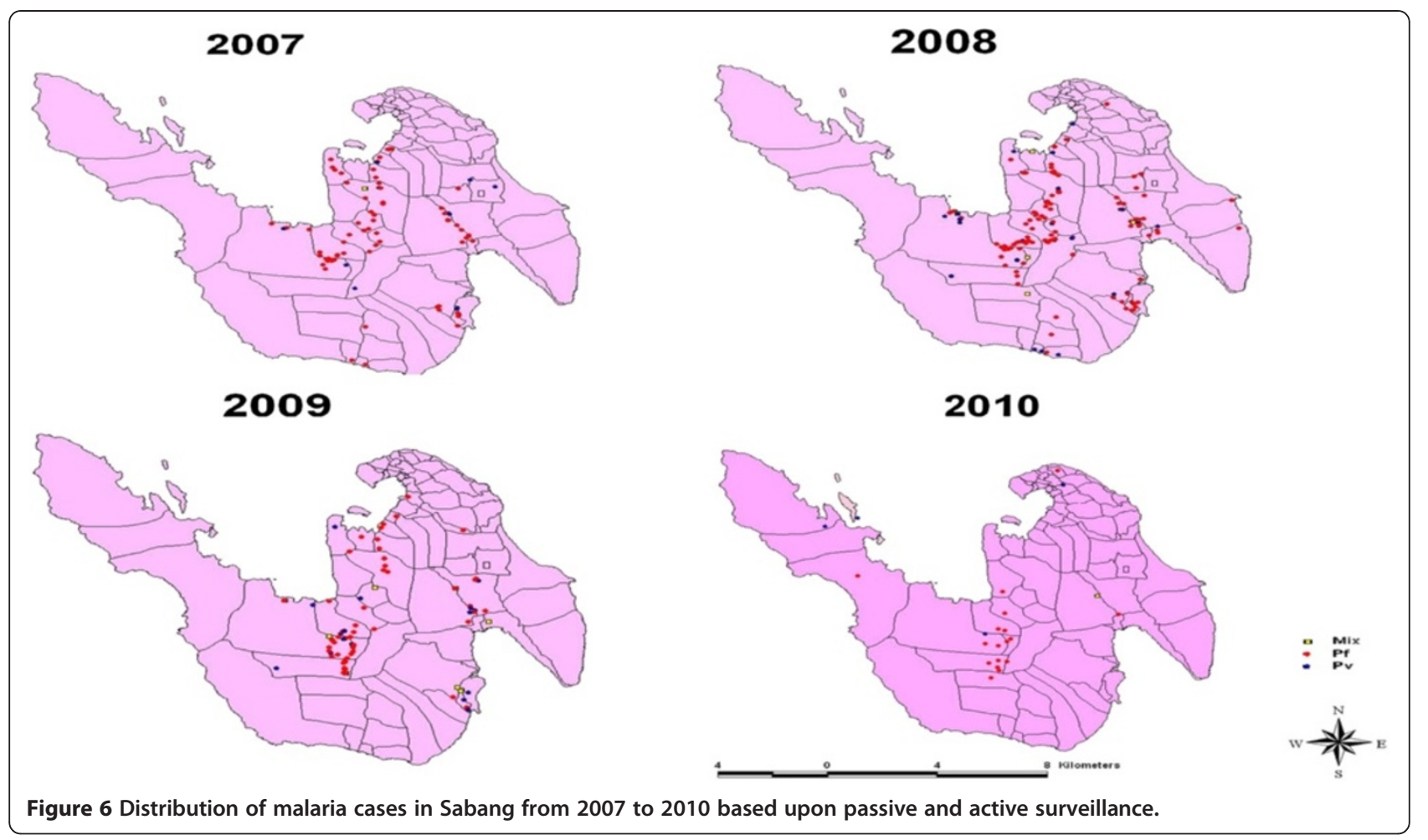

includes information on demography, malaria cases and their therapy, laboratory data, and case follow-up. Information on epidemiologic investigations is also included, as well as survey data. The tool is a web-based application supported by MySQL database, an open source programme, which can be installed either as a standalone or a network. Output of the data can be either as raw data, graphics, maps or tables.

Though this system has been introduced to the public sector, hospitals and the private physicians remain outside the reporting system. Further, discussion showed that the MHA infrequently carried out epidemiological investigations of malaria cases in collaboration with staff from primary health care facilities. Clearly, systemic problems in coordination within the public health system remain, as do problems of communication between the public and private sectors [23].

\section{Stratification of foci area}

Stratification of malaria transmission was conducted twice by the MHA, in July 2009 and December 2011, based upon a modification of WHO criteria [32]. Definitions and distribution of sub-villages in each stratum are shown in Figure 7 [7]. Of note, a reduction in the number of sub-villages in focus $\mathrm{A}$ and $\mathrm{B}$ (ongoing transmission of malaria) reduced from 61 to 43 subvillages during the period in question.

\section{Mass blood screening}

In 2010, 16,229 residents of Sabang were screened for malaria infection. Of these, 19 people were positive, for a point prevalence of $0.12 \%$. Of the 19 positive cases, eight were detected via microscopy and 11 via PCR. Of 57 subjects who were feverish (temperature $>37.5 \mathrm{C}$ ) at the time of survey or showed a history of fever, three of 57 were positive, and these were all detected with microscopy. Of 16 asymptomatic infections, five were detected with microscopy and 11 were detected with PCR. Of the 19 cases, seven were infected with P. falciparum only, 11 were infected with $P$. vivax only, and one subject was infected with both species. Sixteen cases showed no symptoms or history consistent with malaria; of these 16 cases, four were infected with only $P$. falciparum, 11 were pure $P$. vivax infections and one was mixed. Fourteen of 19 infections were from one village: Batee Shok, while the remaining five positive cases were found in Iboih, Paya Kenekai, and Ie Meulee [25].

\section{G6PD deficiency}

Subjects enrolled in the G6PD survey were the head of the household and his wife. Of 937 subjects surveyed, only two were positive $(0.2 \%)$ as mild deficiency. Genomic DNA analysis revealed neither case carried the most common mutations for G6PD deficiency (Mediterranian (563C/T), Coimbra (592 C/T), Vianchang Canton (1376 G/T), Vanua Lava (383 T/C), Mahidol (487 G/T), Chatam (1003 G/A), Kaiping (1388 G/A), Vianchang (871 G/A, 1311 C/T) [25]. 


\section{Discussion}

In this study, interventions were described which have dramatically reduced the burden of malaria in Sabang over the past seven years. The effect on malaria incidence has been dramatic, with a nearly 30 -fold decline in incidence from 3.83 to 0.13 per thousand population from 2008 to 2011 [33]. These now-standard interventions include improved malaria diagnosis, introduction of ACT for malaria treatment, and scale-up of coverage of IRS and LLINs. The backbone of the Sabang programme has been strengthening of its diagnostic system. In 2009, twenty microscopists active in the programme were tested by an expert team according to WHO guidelines; four of the Sabang microscopists tested as expert (level 1), three at reference (level 2), eight at advanced (level 3), and two at basic (level 4). These test results show that Sabang has succeeded in training a cadre of highly proficient microscopists. By 2009, blood slides from $96 \%$ of suspected malaria cases were examined by this capable team - up from $66 \%$ in 2004 . The small number of cases not confirmed via microscopy was tested using RDTs. Near universal coverage of microscopic diagnosis was coupled with introduction of use of ACT for treatment of all forms of malaria (including $P$. vivax) in 2005. By the end of 2009, 94\% of laboratory-confirmed cases of malaria in Sabang were treated with ACT [17].

After the prohibition and cessation of DDT spraying in Indonesia in 1992, only occasional IRS was carried out in Sabang until the post-tsunami period when, from
2005 - 2007, the government of Sabang, in collaboration with the Mentor Initiative (an international NGO), carried out three-times yearly spraying with alphacypermethrin in 18 villages, with reported coverage of 50-60\% [34]. LLINs were introduced to Sabang after the tsunami, with more than 15,000 nets distributed since 2005 by the government of Sabang in collaboration with CARE International and UNICEF [35]. While coverage of LLINs in the six focal villages remains high, at over $75 \%$, data from previous surveys are mixed [23]. In July 2005. Samaritan's Purse and Mentor reported that $98 \%$ of households owned at least one LLIN [34]. A survey by community volunteers conducted in February 2006 showed that $88 \%$ of households owned an LLIN, with reported usage rates by children under five years of age of $74 \%$ [35]. In contrast, Demographic Health Survey (DHS) results for 2007 showed that only $22 \%$ of households owned an LLIN. The likely reason for this discrepancy is that the DHS results included urban parts of Sabang, which were not targeted by the LLIN campaigns, while the previous surveys used as their sampling frame only rural areas targeted for LLIN distribution [36]. In addition to interventions targeting adult mosquitoes, focal application of the larval growth regulator pyriproxyfen was carried out in five villages from 2005 2007 [6].

Sabang, in accordance with official policy of the $\mathrm{MOH}$ of Indonesia, has taken the bold step of explicitly aiming to eliminate malaria transmission by the end of 2013 [17]. The

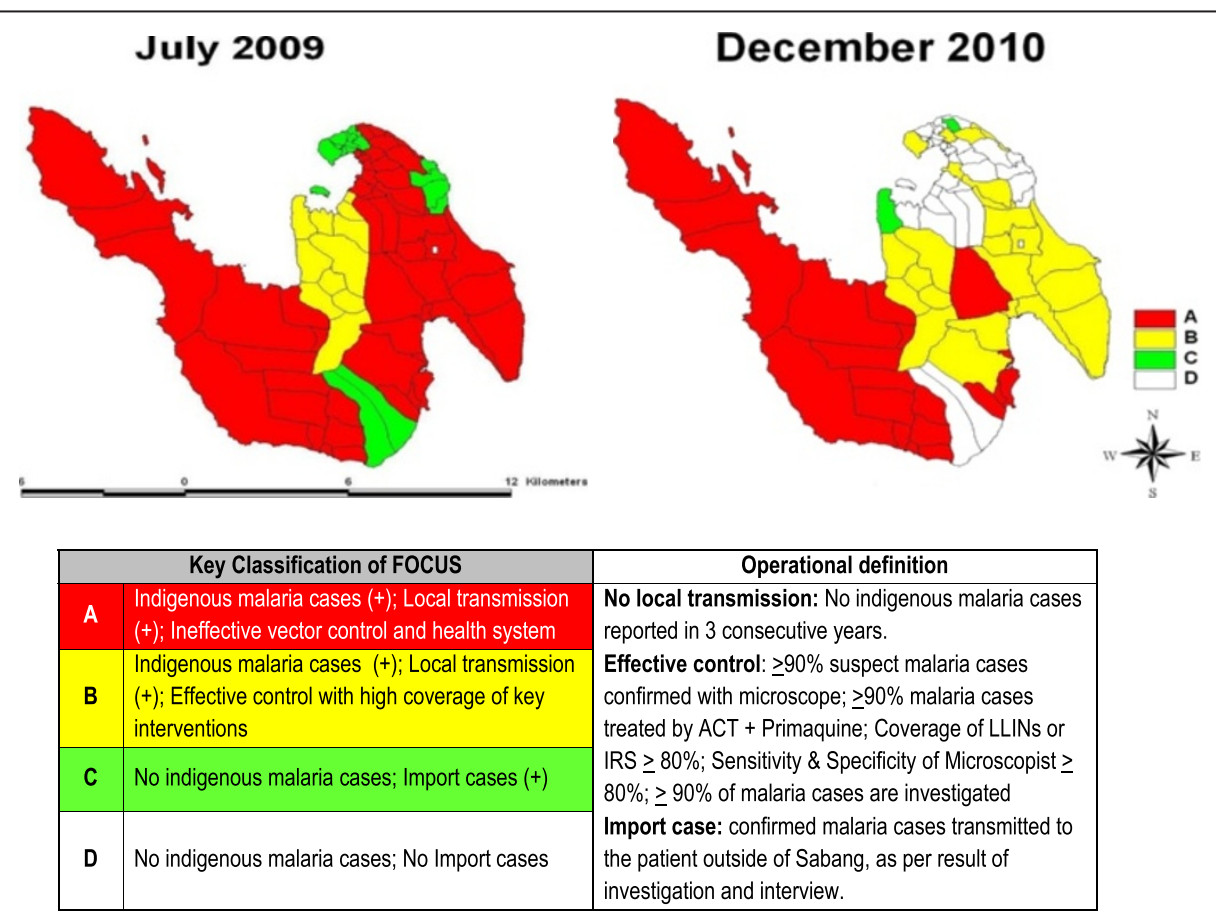

Figure 7 Classification of Malaria Foci in Sabang. 
government of Sabang is pursuing this policy aggressively, and recognizes that the key to elimination is rapid reporting and accurate information. As described above, the routine diagnosis capability with the $\mathrm{MOH}$ has been steadily strengthened over the past seven years. Since mid-2009, private practitioners are asked to send blood smears to government clinics for malaria diagnosis. In May 2010, the $\mathrm{MOH}$ set up a system of village volunteers for active case detection. One volunteer has been recruited for each subvillage. To date, 78 volunteers have been recruited, trained, and certified by the government. In the 14 villages classified as 'active' or 'residual active' (foci A and B in Figure 6) home visits are conducted twice monthly, while in non-active foci monthly visits are carried. Blood smears are taken from anyone with fever or recent history of fever and sent to the nearest community health centre. Confirmed cases are treated by health centre staff at the patient's home, using directly observed treatment. The volunteer takes follow-up smears on days 3, 7, 14, 28 and (for P. vivax only) 90 [17].

Since August 2010, all cases of malaria detected through passive or active surveillance, via either government or private practitioners, are investigated by staff from the community health centre and the municipal health office. The investigation is adapted from the procedure used in Zanzibar [37], with four steps: 1) Interview to determine travel history, blood transfusion history, or contact with malaria patients; 2) Contact survey - taking of blood smears from family members and all neighbors within 500 meters of the index case; 3) Rapid assessment of anopheles larval habitats and biting activity by the district's entomology team; 4) Input of information into the malaria database and classification of the case as indigenous or imported. Since 2009, every case, whether detected passively or actively, has been included in the database, with information on age, sex, occupation and other aspects that may influence a person's malaria risk); history of disease (travel history, fever/malaria history, contact history); all information related to malaria diagnosis; treatment; notification of case and epidemiology investigation (indigenous, import, induction, introduction, relapsed), source of cases (passive case detection, active case detection, survey), location (including GPS coordinates), and nearby Anopheles larval habitats [17].

The emphasis on mapping larval habitats near transmission is appropriate in the context of Indonesia, as some, but not all, malaria vectors in the country are amenable to larval control via environmental management. In the malaria database, information on coverage of LLINs and IRS is linked to foci of transmission [23], so that interventions targeting larvae may be carried out should transmission continue even though coverage of interventions targeting adults is high. Effective larval control might also allow the possibility for scaling back in IRS and LLIN coverage, as continuous high coverage is difficult to support politically as malaria incidence declines to near zero levels [38].

In Sabang, as throughout Indonesia and much of southeast and south Asia, both $P$. falciparum and $P$. vivax are common $[9,10,39]$. The steps taken after successful control of malaria in Sabang - improved reporting, coordination with the private sector, active case detection, mapping of cases and mosquito habitats may be sufficient to eliminate malaria on the island. However, results of our mass screening of nearly half of the population of Sabang raise doubts on the likelihood of success, especially for $P$. vivax. Of note, only three of the 19 cases detected in the survey were symptomatic, and these were all detected with microscopy. Of 16 asymptomatic cases, five were detected with microscopy, while the balance of 11 cases was detected with PCR. Of these 11 asymptomatic cases, 10 were pure $P$. vivax infections, and all of these were detected via PCR. Thus, for both species of parasite, but more so for $P$. vivax, subpatent, asymptomatic infections were found via PCR that were not detectable with microscopy [24]. Indeed, by extrapolation from this survey, about 165 asymptomatic infections of malaria - mostly $P$. vivax - were present in Sabang at the time of the survey, all undetectable by the microscopy. Even though Sabang's programme is based upon rapid detection, reporting, and intervention with diagnosis via conventional microscopy, it may still be possible to eliminate malaria on the island without resorting to mass treatment or expensive screening via PCR. Whether elimination is possible will depend upon the balance between the efficiency of the programme, and the rate at which subpatent, asymptomatic infections recrudesce allowing detection and attack via medication - or spontaneously disappear [39-41]. Both processes are known to occur. An important third unknown parameter is the probability of transmission of subpatent infections to mosquitos [42]. Though presumably low, this probability can be further minimized via vector control interventions targeting both adults and larvae. These three parameters presumably vary between the two parasite species. The higher prevalence of asymptomatic $P$. vivax infections, coupled with the operational difficulty of radical treatment of hypnozoites, makes is likely that this parasite will be more difficult to eliminate than $P$. falciparum $[8,39,43,44]$.

Aggressive efforts to treat $P$. vivax carry risks associated with G6PD deficiency $[45,46]$. Though reported prevalence in Sabang is low, based upon results of our survey, it is possible that other parts of Indonesia [29-31,47] or other parts of Asia [30,48], may have higher levels of this risk factor. Minimization of this risk will require availability of cheap and effective rapid screening tests for G6PD deficiency or better anti-hypnozoite drugs, but neither of 
these is available now [39,49-51]. Further, the current anti-hypnozoite drug, primaquine, must be taken over 14 days by patients that already feel recovered, raising serious problems with patient compliance [50,51].

Further complicating malaria elimination efforts in Sabang is the high mobility of Indonesians, and the fact that many Indonesians may seek employment in parts of Aceh, Kalimantan or eastern Indonesia, where risk of malaria infection is substantial. A recent imported case of malaria to Sabang in a gold miner illustrates this point. Sabang will need to establish good community based systems for screening and detection of malaria in residents returning from malaria endemic areas. Such a system has been established in Wonosobo, central Java [52], which sends many temporary workers to malariaendemic Kalimantan. Sabang has, as yet, not set up any systems to specifically detect imported cases. Perhaps of greater importance are efforts on the part of the $\mathrm{MOH}$ to reduce malaria incidence throughout the country. Malaria incidence has declined in eastern Indonesia thanks to scale up of many of the same interventions rolled out in Sabang, but many pockets of high transmission remain, and these are all potential sources of imported malaria to Sabang.

\section{Consent}

All surveillance activities described in this report were consistent with and conform to policies set by the Ministry of Health of the Republic of Indonesia.

\section{Abbreviations}

ACT: Artemisinin-based combination therapy; DDT: Dichloro-diphenyltrichloroethane; GPS: Global positioning system; G6PD: Glucose-6-phosphate dehydrogenase; HHs: Households; IRS: Indoor residual spraying; LLINs: Longlasting insectide-treated nets; MHA: Municipal health authority; NGO: Nongovernment organization; PCR: Polymerase chain reaction; RFLP: Restriction fragment length polymorphisms; RDTs: Rapid diagnostic tests;

UNICEF: United nation children's fund; WHO: World health organization.

\section{Competing interest}

The authors declare that they have no competing interests.

\section{Authors' contributions}

$\mathrm{HH}$ and WH wrote the whole paper. PBSA and DS contributed in mass blood screening and G6PD, HK and AF contributed in mapping malaria database, $\mathrm{SZ}, \mathrm{RRA}, \mathrm{HH}$ contributed in vector assessment. Overall survey was designed by HH, WH, RRA, MES, TY, Al, RR, MY, and FL. After survey, HH, PBSA, SZ, RRA, $A F$, and $W H$ analysed, interpreted the results and drafted the manuscript. FL, RR, MY, SNT, and RK contributed in providing secondary data and inputs. All authors critically reviewed the manuscripts and approved the final version before submission.

\section{Acknowledgements}

The authors are grateful to all malaria microscopists, head of primary centres, malaria officers, surveillance officers, and malaria volunteer at subdistrict level in Sabang for succeeding the survey. We thank the survey team from the Sabang municipal health office: Mardiati, Nurlela, Kurniawan, and Zulfan. The opinions expressed in this paper are those of the authors and may not reflect the position of their employing organizations nor their work's sources of funding.

\section{Funding}

These studies were funded by UNICEF Indonesia.

\section{Author details}

${ }^{1}$ Child Survival and Development Cluster, UNICEF Indonesia Country Office, Jalan Sudirman Kav. 31, Wisma Metropolitan II, Fl 10th, Jakarta 12920, Indonesia. ${ }^{2}$ Faculty of Medicine, University of Gadjah Mada, Yogyakarta, Indonesia. ${ }^{3}$ Eijkman Institute for Molecular Biology, Jalan Diponegoro, 69, Jakarta 10430, Indonesia. ${ }^{4}$ Ministry of Health, Directorate of Vector Borne and Zoonotic Diseases, Jakarta, Indonesia. ${ }^{5}$ Municipal Health Authority of Sabang, Jalan By Pass Cot Ba'U, Sabang, Province of Aceh, Indonesia. ${ }^{6}$ Provincial Health Authority of Aceh Province, Banda Aceh, Aceh Province, Indonesia.

Received: 30 July 2012 Accepted: 25 January 2013

Published: 30 January 2013

\section{References}

1. The Global Health Group and the Malaria Atlas Project: Atlas of the Asia Pacific Malaria Elimination Network, 2011. San Francisco: The Global Health Group, Global Health Sciences, University of California, San Francisco; 2011.

2. World Health Organization Global Malaria Programme: World Malaria Report. Switzerland: WHO Press; 2011

3. Murray CJ, Rosenfeld LC, Lim SS, Andrews KG, Foreman KJ, Haring D, Fullman N, Naghavi M, Lozano R, Lopez AD: Global malaria mortality between 1980 and 2010: a systematic analysis. Lancet 2012, 379:413-431.

4. Departemen Kesehatan: Keputusan Menteri Kesehatan Republik Indonesia Nomor 293/MENKES/SKIV/2009 28 April 2009 tentang Eliminasi Malaria di Indonesia. Jakarta: Direktorat Pemberantasan Penyakit Bersumber Binatang, Departemen Kesehatan Indonesia; 2009.

5. Machmud S: Pelabuhan Bebas Sabang, 1967. Banda Aceh: Lembaga Penyelidikan Ekonomi dan Sosial Universitas Syah Kuala; 1968:38.

6. Dinas Kesehatan Kota Sabang: Laporan Program Malaria Tahun 2001 - 2007 Kota Sabang: Dinas Kesehatan Kota Sabang; 2008.

7. Gubernur Aceh: Peraturan Gubernur Aceh No. 40 Tahun 2010 tentang Pedoman Eliminasi Malaria Elimination di Aceh. Banda Aceh: Pemerintah Provinsi Aceh; 2010.

8. World Health Organization: Malaria Elimination, a field manual for low and moderate endemic countries. Geneva: WHO Press; 2007.

9. Elyazar IRF, Gething PW, Patil AP, Rogayah H, Kusriastuti R, Wismarini DM, Tarmizi SN, Baird JK, Hay SI: Plasmodium falciparum malaria endemicity in Indonesia in 2010. PLoS One 2011, 6:e21315.

10. Elyazar IRF, Gething PW, Patil AP, Rogayah H, Sariwati E, Palupi NW, Tarmizi SN, Kusriastuti R, Baird JK, Hay SI: Plasmodium vivax malaria endemicity in Indonesia in 2010. PLoS One 2012, 7:e37325.

11. Heywood P, Choi Y: Health system performance at the district level in Indonesia after decentralization. BMC Int Health Hum Rights 2010, 10:3.

12. Badan Pusat Statistik: Sabang dalam Angka Tahun 2007. Kota Sabang: Badan Pusat Statistik Indonesia; 2008.

13. Badan Pusat Statistik: Sabang dalam Angka Tahun 2010. Kota Sabang: Badan Pusat Statistik Indonesia; 2011.

14. Hudson JE: Survey of Malaria Mosquito in The Special Province of Aceh, Indonesia, July - August 1985. Belgium: Consultancy report to Province of Antwrep; 1986.

15. Ompusunggu S, Arbani PR, Marwoto HA, Sekar Tuti E, Suwarni: Sensitivitas plasmodium falciparum secara in vitro terhadap beberapa macam obat di Sabang, Aceh. Cermin Dunia Kedokteran 1989, 54:19-21.

16. Elyazar IRF, Hay SI, Baird JK: Malaria distribution, prevalence, drug resistance and control in Indonesia. Adv Parasitol 2011, 74:41-175.

17. Departemen Kesehatan Republik Indonesia, Pemerintah Aceh, Pemerintah Kota Sabang, UNICEF: Laporan Kegiatan Program Malaria Menuju Pembebasan Provinsi Aceh Tahun Anggaran 2009. Banda Aceh: Dinas Kesehatan Aceh; 2010.

18. WHO: Malaria entomology and vector control - Learner's Guide. Geneva: World Health Organization; 2003.

19. WHO: Malaria entomology and vector control - Tutor's Guide. Geneva: World Health Organization; 2003.

20. Reid JA: Anopheline mosquitoes of Malaya and Borneo. Stud Inst Med Res Malaya 1968, 31:1-520.

21. O'Connor CT, Soepanto: Illustrated key to female anophelines of Indonesia (revised by Atmosoedjono S and Bangs MJ, NAMRU-2). Jakarta: Directorate of Communicable Disease, Ministry of Health Indonesia; 1989. 
22. Herdiana, Arisanti RR, Zubaedah S, Sumiwi ME, Kurniawan, Yuniarti T, Imran A: Report on Mapping of Malaria Vector in Sabang: Baseline for focus intervention toward malaria elimination goal: Joint report of Municipal Health Office of Sabang and UNICEF Banda Aceh; Dinas Kesehatan Kota Sabang; 2008.

23. Koesnanto H, Fuad A, Satoto TBT, Widagdo A, Prasetyo AKN, Lazuardi L, Prasetyo H: Malaria Elimination Database Development in Sabang, Final report of Center of Health Management and Informatic System, University of Gadjah Mada to UNICEF. Yogyakarta: University of Gadjah Mada; 2010.

24. Maguire JD, Lederman ER, Barcus MJ, O'Meara WAP, Jordon RG, Duong S, Muth S, Sismadi P, Bangs MJ, Prescott WR, Baird JK, Wongsrichanalai C: Production and validation of durable, high quality standardized malaria microscopy slides for teaching, testing and quality assurance during an era of declining diagnostic proficiency. Malar J 2006, 5:92.

25. Asih PB, Rozi IE, Pratama NR, Hidayati APN, Marantina SS, Chand K, Suradi, Rusdjy FA, Sumiwi ME, Rahmadyani, Yani M, Imran A, Jamil K, Mariam C, Syafruddin D: Mass blood screening and treatment in the initial phase of malaria elimination in Sabang District, Indonesia: Final Report of Eijkman Institute for Molecular Biology to UNICEF. Jakarta: Eijkman Institute; 2010.

26. Tantular IS, Kawamoto F: An improved, simple screening method for detection of glucose-6-phosphate dehydrogenase deficiency. Trop Med Int Health 2003, 8:569-574.

27. Wooden J, Kyes S, Sibley CH: PCR and strain identification in plasmodium falciparum. Parasitol Today 1993, 9:303-305.

28. Moll K, Ljungström I, Perlmann H, Scherf A, Wahlgren M: Methods in Malaria Research. Manassa, Virginia: Malaria Research and Reference Reagent Resource Center (MR4) American Type Culture Collection; 2008.

29. Matsuoka H, Arai M, Yoshida S, Tantular IS, Pusarawati S, Kerong H, Kawamoto F: Five different glucose-6-phophate dehydrogenase (G6PD) variants found among 11 G6PD-deficient persons in Flores Island, Indonesia. J Hum Genet 2003, 48:541-544.

30. Iwai K, Hirono A, Matsuoka H, Kawamoto F, Horie T, Lin K, Tantular IS, Dachlan YP, Notopuro H, Hidayah NI, Salim AM, Fujii H, Miwa S, Ishii A: Distribution of glucose-6-phosphate dehydrogenase mutations in Southeast Asia. Hum Genet 2001, 108:445-449.

31. Soemantri AG, Saha S, Saha N, Tay JS: Molecular variants of red cell glucose-6-phosphate dehydrogenase deficiency in Central Java, Indonesia. Hum Hered 1995, 45:346-350.

32. World Health Organization, EMRO Technical Publications Series 33 Guidelines on the elimination of residual foci of malaria transmission. Cario: WHO Regional Office for the Eastern Mediterranean; 2007.

33. Kementerian Kesehatan Republik Indonesia, Pemerintah Aceh, Pemerintah Kota Sabang, Pemerintah Kabupaten Aceh Timur, Pemerintah Kabupaten Aceh Besar, Pemerintah Kabupaten Aceh Jaya, UNICEF: Laporan Kegiatan Program Malaria Menuju Pembebasan Provinsi Aceh Tahun Anggaran 2011. Banda Aceh: Dinas Kesehatan Aceh; 2012.

34. Mentor Initiative: Annual Report Malaria Programme in Emergency. The Tsunami Response, A report to Badan Rehabilitasi dan Rekonstruksi Aceh. Banda Aceh: Mentor Initiative; 2005

35. Herdiana: Monitoring Report of Free Malaria Campaign in Aceh and North Sumatera Province, 2005 - 2007, Join report of UNICEF, American Red Cross and Provincial Health Office of Aceh and North Sumatera. Banda Aceh: UNICEF Indonesia; 2008.

36. UNICEF, Statistics Indonesia (Badan Pusat Statistik-BPS) and Macro International: Aceh Province and Nias Island Demographic and Health Survey Data report 2007. Jakarta: UNICEF, BPS and Macro International; 2010.

37. Zanzibar Malaria Control Programme: Ministry of Health and Social Welfare: Malaria elimination in Zanzibar: a feasibility assessment October 2010. Zanzibar: Zanzibar Malaria Control Program, Ministry of Health and Social Welfare; 2010.

38. Faraj C, Adlaoui E, Ouahabi S, Rhajaoui M, Fontenille D, Lygoubi M: Entomological investigation in the region of the last malaria focus in Morroco. Acta Trop 2009, 109:70-73.

39. Feachem RGA, Philips AA, Targett GA: Shrinking The Malaria Map A Prospectus on Malaria Elimination. San Fransisco: The Global Health Group, Global Health Sciences, University of California, San Fransisco; 2009.

40. Moonen B, Chone JM, Snow RW, Slutsker L, Drakeley C, Smith DL, Abeyasinghe RR, Rodriguez MH, Maharaj R, Tanner M, Targett G: Operational strategies to achieve and maintain malaria elimination. Lancet 2010, 376:1592-1603.
41. The Pacific Malaria Initiative Survey Group (PMISG) on behalf of the Ministries of Health of Vanuatuand Solomon Islands: Malaria on isolated Melanesian islands prior to the initiation of malaria elimination activities. Malar J 2010, 9:218.

42. Alves FP, Gil LH, Marrelli MT, Ribolla PE, Camargo EP, Da Silva LH: Asymptomatic carriers of plasmodium spp. As infection source for malaria vector mosquitoes in the Brazilian Amazon. J Med Entomol 2005 42:777-779.

43. Price RN, Tjitra E, Guerra CA, Yeung S, White NJ, Anstey NM: Vivax malaria: neglected and not benign. AmJ Trop Med Hyg 2007, 77:79-87.

44. Wells T, Burrows J, Baidr J: Targeting the hypnozoite reservoir of plasmodium vivax: the hidden obstacle to malaria elimination. Trends Parasitol 2010, 26:145

45. Beutler E: G6PD deficiency. Blood 1994, 84:3613-3636.

46. Cappellini MD, Fiorelli G: Glucose-6-phosphate dehydrogenase deficiency. Lancet 2008, 371:64-74.

47. Tantular IS, Matsuoka H, Kasahara Y, Pusarawati S, Kanbe T, Tuda JSB, Kido Y Dachlan YP, Kawamoto F: Incidence and mutation analysis of glucose-6phosphate dehydrogenase deficiency in eastern Indonesia populations. Acta Med Okayama 2010, 64:367-373.

48. Phompradit P, Kuesap J, Chaijaroenkul W, Rueangweerayut R, Hongkaew Y, Yamnuan R, Na-Bangchang K: Prevalence and distribution of glucose-6phosphate dehydrogenase (G6PD) variatns in Thai and Burmese population in malaria endemic areas of Thailand. Malar J 2011, 10:368.

49. White NJ: The role of anti-malarial drugs in eliminating malaria. Malar J 2008, 7(Suppl 1):S8.

50. Hill DR, Baird JK, Parise ME, Lewis LS, Ryan ET, Magill AJ: Primaquine: report from CDC expert meeting on malaria chemoprophylaxis. AmJ Trop Med Hyg 2006, 75:402-415.

51. Fernando D, Rodrigo C, Rajapakse S: Primaquine in vivax malaria: an update and review on management issues. Malar J 2011, 10:351.

52. Junaidi: Situasi Penemuan Kasus dan Pengendalian Malaria di Kabupaten Wonosob Tahun 2011, Disampaikan pada Pertemuan Kunjungan Kerja Pemerintah Kota Sabang ke Kabupaten Wonosobo. Wonosobo: Dinas Kesehatan Kabupaten Wonosobo; 2011.

doi:10.1186/1475-2875-12-42

Cite this article as: Herdiana et al:: Progress towards malaria elimination in Sabang Municipality, Aceh, Indonesia. Malaria Journal 2013 12:42.

\section{Submit your next manuscript to BioMed Central and take full advantage of:}

- Convenient online submission

- Thorough peer review

- No space constraints or color figure charges

- Immediate publication on acceptance

- Inclusion in PubMed, CAS, Scopus and Google Scholar

- Research which is freely available for redistribution 